\title{
Testosterone treatment and cardiovascular and venous thromboembolism risk: what is 'new'?
}

\author{
G Corona, ${ }^{1}$ M Dicuio, ${ }^{2,3}$ G Rastrelli, ${ }^{4}$ E Maserolii, ${ }^{4} \mathrm{~F}$ Lotti, ${ }^{4}$ A Sforza, ${ }^{1}$ \\ M Maggi $^{4}$
}

Additional material is published online only. To view please visit the journal online (http://dx.doi.org/10. 1136/jim-2017-000411).

${ }^{1}$ Endocrinology Unit, Medical Department, MaggioreBellaria Hospital, AziendaUsl Bologna, Bologna, Italy ${ }^{2}$ Urology Unit, Maggiore Hospital, Bologna, Italy ${ }^{3}$ Department of Urology, Sahlgrenska University Hospital, Göteborg, Sweden ${ }^{4}$ Sexual Medicine and Andrology Unit, Department of Experimental, Clinical and Biomedical Sciences, University of Florence, Florence, Italy

\section{Correspondence to} Professor Mario Maggi, Sexual Medicine and Andrology Unit, Department of Experimental, Clinical and Biomedical Sciences, University of Florence, Florence, Italy. Viale Pieraccini 6, Florence 50139, Italy; m.maggi@dfc.unifi.it

Accepted 19 April 2017 Published Online First 10 May 2017

Copyright $@ 2017$ American Federation for Medical Research

\section{ABSTRACT}

In men, testosterone (T) production declines as a function of ageing. Late-onset hypogonadism ( $\mathrm{LOH})$ is the most commonly used term to indicate this age-related condition. In $\mathrm{LOH}$, the relative clinical significance and the potential benefit of testosterone treatment (TTh) are still the subject of strong criticisms in the scientific community. The debate is further complicated by the recent position statement of the US Food and Drug Administration (FDA) emphasizing that, in $\mathrm{LOH}$, the benefits and safety of TTh have not been fully established. Hence, the FDA required a labeling change to inform patients about a possible increased cardiovascular (CV) risk of TTh. Similar considerations were previously released by the FDA and by Health Canada concerning a TThrelated venous thromboembolism (VTE) risk. In this review, we will summarize the available evidence concerning a possible link among TTh and CV and VTE risks. For this purpose, data derived from epidemiological studies analyzing relationships between the aforementioned risks and endogenous T levels will be analyzed. In addition, evidence deriving from interventional studies including pharmacoepidemiological and placebo-controlled randomized controlled trials (RCTs) will be examined. Our analysis shows that available data do not support an increased CV risk related to TTh. Similar considerations can be drawn for the relationship between TTh and VTE. The previously reported cases of TTh-related VTE were frequently related to a previously undiagnosed thrombophiliahypofibrinolysis status. Hence, an anamnestic screening for thrombophilia before starting TTh is recommended, just as it is for the use of oral contraceptives.

\section{INTRODUCTION}

Testosterone (T) is the main androgen secreted by the male gonadal gland and its biological actions and effects depend on the different life stages. During the fetal stage, $\mathrm{T}$ is mainly involved in the differentiation of internal genitalia and in the testis descent, whereas its $5 \alpha$ reduced dihydrotestosterone is essential for prostate and external genital differentiation. During puberty, under $\mathrm{T}$ regulation, secondary sexual characteristics appear, fertility is achieved and the adolescent growth spurt occurs. $^{1-3}$ In adulthood, $\mathrm{T}$ modulates penile erection-as well as other sexual behaviors and attitudes ${ }^{4}$-and is also involved in the regulation of body composition, including glycometabolic homeostasis. ${ }^{5-7}$ Furthermore, T and, in particular, its aromatized metabolite, oestradiol, contributes to bone metabolism. ${ }^{8}$ Finally, a possible role for $\mathrm{T}$ in mood regulation and well-being has also been suggested.

Epidemiological data indicate that $\mathrm{T}$ production declines progressively as a function of age and that a significant percentage of men over the age of 60 have serum $\mathrm{T}$ levels below the lower limits of young adult men. ${ }^{1}$ Late-onset hypogonadism (LOH) is the most commonly used term to indicate this condition. ${ }^{1}$ However, the clinical significance of $\mathrm{LOH}$ is still the subject of strong criticisms in the scientific community. In particular, it is not clear whether reduced $\mathrm{T}$ levels observed in ageing males play a direct contribution to ageing-related morbidities and symptoms or whether low $\mathrm{T}$ and associated morbidities are concomitant conditions, both associated with the ageing process per se. ${ }^{1} 910$

The debate about $\mathrm{LOH}$ was further complicated by a recent position statement of the US Food and Drug Administration (FDA). In fact, in its final 2015 release, the FDA cautioned prescribing $\mathrm{T}$ products, stating that they should be only considered for men with 'classical hypogonadism', that is, due to primary or secondary $\mathrm{T}$ deficiency resulting from known problems within the testis, pituitary, or hypothalamus (eg, genetic problems, or damage from surgery, chemotherapy, or infection). In addition, the FDA stressed the lack of conclusive data on the benefits and safety of $\mathrm{T}$ medications in ageing men. ${ }^{11}$ Similar considerations were released in 2014 for the risk of venous thromboembolism (VTE) by the FDA and Health Canada. ${ }^{12}{ }^{13}$ Recently, this position has been essentially endorsed by the Australian Society of Endocrinology. ${ }^{14}$

The aim of this review is to summarize the available evidence supporting a possible link among LOH, cardiovascular (CV) and VTE risks. In particular, for this purpose, three different types of information will be scrutinized concerning LOH and CV or VTE risk: (1) data derived from epidemiological studies analyzing relationships between the aforementioned risks and endogenous T levels; (2) data derived from pharmacoepidemiological studies investigating the effect of T treatment (TTh); and (3) data derived from the use of TTh in placebo-controlled randomized controlled trials (RCTs). Results from 
already published meta-analyses will be discussed and analyzed and, in addition, some new meta-analytic analyses will be provided.

\section{CARDIOVASCULAR SAFETY}

Acute or chronic illnesses might interfere with the hypothalamic-pituitary-testis axis activity, leading to the development of primary or, more frequently, secondary hypogonadism. It can be speculated that the reduction of $\mathrm{T}$ in unfavorable situations-such as in acute or chronic illnesses-might represent a protective mechanism, turning off T-dependent functions (such as reproduction and/or physical and sexual activity) that are not desirable when the physical condition is ailing. ${ }^{9}$ Similar adaptive mechanisms have been previously described for other hormonal axes. ${ }^{15}$ In line with this possibility, we previously reported in a series of more than 1600 subjects with sexual dysfunction -followed longitudinally for a mean follow-up of 4.3 years-that hypogonadism (total $\mathrm{T}<12 \mathrm{nmol} / \mathrm{L}$ or $350 \mathrm{ng} / \mathrm{dL}$ ) was associated with a lower (and not higher) incidence of new CV events in those men who had already suffered from CV diseases (CVD) or obesity at enrollment. ${ }^{16}{ }^{17}$ Similar results have been reported in subjects with HIV-related hypogonadism. ${ }^{18}$ In line with these data, reports in the scientific and lay press significantly halted the enthusiasm on androgen boosting, suggesting that TTh does increase $\mathrm{CV}$ risk. Accordingly, the $\mathrm{FDA}^{11}$ and the Australian Endocrinology Society ${ }^{14}$ stressed the lack of conclusive data on the benefits and safety of T medications in ageing men. In addition, the FDA has mandated pharmaceutical companies that market patented $\mathrm{T}$ delivery systems to conduct a placebo-controlled trial that is powered to address potential CV events. ${ }^{19}$ It is likely that the trial will involve 5000-6000 hypogonadal men and treatment will last up to 6 years.

Available evidence regarding the possible relationship between TTh and CV risk will be analyzed in more detail in the following sections.

\section{Relationship between endogenous T levels and CV risk}

By meta-analyzing available population-based data, three independent meta-analyses have failed to show an association between baseline low $\mathrm{T}$ and incident $\mathrm{CVD} .{ }^{20-22}$ Conversely, a significant increase in the risk of incident CV mortality for subjects with low $\mathrm{T}$ has been reported in one meta-analysis, ${ }^{22}$ while in others a non-significant trend toward an increase was observed. ${ }^{20}{ }^{21}$ In addition, heterogeneity in the primary data was also observed. Hence, a possible alternative conclusion is that low $\mathrm{T}$ could be reflective of an overall poorer health status and not causally related to increased CV mortality. ${ }^{20-23}$

\section{Pharmacoepidemiological studies}

Pharmacoepidemiology is a science dealing with the analysis of efficacy and safety of drugs in specific populations. ${ }^{24}$ The advantage of pharmacoepidemiology when compared to RCTs is the possibility to assess the incidence of adverse events during long periods of follow-up. Two large observational register studies published in 2013 and 2014 generated great acclaim in the scientific community, suggesting an increased CV risk related to TTh. The first study was based on a retrospective analysis of a cohort of
8709 American Veterans (VA) with reduced $\mathrm{T}$ levels $(\mathrm{T}<10.4 \mathrm{nmol} / \mathrm{L})$, who underwent coronary angiography between 2005 and $2011 .^{25}$ Among the VA cohort, those that received TTh during the follow-up period had an increased risk of major adverse cardiovascular events (MACE) or death from any cause when compared with those who were untreated with $\mathrm{T}^{25}$ The main criticisms related to this study deal with the lack of $\mathrm{T}$ measurements during the follow-up and with the treatment inadequacy in many of the included cases. ${ }^{1026}$

Some months later the publication of Vigen et $a l^{25}$ a subsequent study of Finkle et al, ${ }^{27}$ further supported a TTh-related CV risk. The latter study reports the analysis of a large Medicare insurance database (55 593 subjects) comparing the rate of heart events in the 90 days after starting TTh with the rate in the prior year. The authors concluded that TTh doubled the risk of heart attack among men aged 65 years and older, and particularly in younger men with a pre-existing history of heart disease. The data were compared to 167000 individuals who were prescribed a phosphodiesterase type 5 inhibitor (PDE5i) without any increase in CV events. However, it is important to recognize that comparison of TTh with PDE5i is questionable, because PDE5i has distinct cardioprotective effects. $^{27}$ Besides these two studies, several other reports were previously and thereafter published (table $1^{2628-36}$ ).

Overall, 12 studies have been published so far, including 185801 cases and 1160325 controls (table 1). Among them, six studies compared the effect of TTh in hypogonadal men versus untreated hypogonadal men. In the other six studies, the effect of $\mathrm{T}$ prescription was compared with subjects who were not prescribed $\mathrm{T}$. In the latter cases, limited information regarding the $\mathrm{T}$ levels was available (table 1). Overall, an increased CV risk was reported only in the Vigen $e t a l^{25}$ and Finkle $e t a l^{27}$ studies. Conversely, in all other reports a neutral or beneficial effect of TTh was found either when overall mortality or myocardial infarction risks were analyzed (table 1). It is important to recognize that, despite their strengths, observational clinical research presents remarkable limitations, which include selection, information, and confounding biases. Hence, results from observational studies showing small differences should be evaluated with caution. In particular, one of the most important limitations of the observational trials is the presence of limited information regarding the level of $\mathrm{T}$ before and during TTh, the number of the controls performed, the dosages used, and the levels of hematocrit. This issue is particularly relevant because a recent report showed that in the USA, among a sample of nearly 250000 men, only $72 \%$ had a claim submitted for T level testing prior to receiving a TTh prescription; $21 \%$ never had any claim; and only $6 \%$ had claims submitted after receiving their initial TTh prescription. ${ }^{37}$ In addition, a general healthcare population survey including more than 4700 hypogonadal men (total $\mathrm{T}<212 \mathrm{ng} / \mathrm{dL} ; 7.3 \mathrm{nmol} / \mathrm{L}$ ) treated with $\mathrm{T}$ documented that the normalization of $\mathrm{T}$ during the treatment was associated with a reduced MACE and death risk over 3 years of follow-up. ${ }^{37}$

\section{Randomized controlled trials}

RCTs are often considered the gold standard for testing a specific treatment. The people participating in trials are 
Table 1 Descriptive characteristics of the available pharmacoepidemiological studies evaluating the impact of testosterone treatment on forthcoming overall mortality or myocardial infarction

\begin{tabular}{|c|c|c|c|c|c|c|c|c|}
\hline Study & $\begin{array}{l}\text { Age } \\
\text { (years) } \\
\text { mean/ } \\
\text { range }\end{array}$ & $\begin{array}{l}\text { n (cases/ } \\
\text { controls) }\end{array}$ & $\begin{array}{l}\text { Follow-up } \\
\text { (weeks) }\end{array}$ & $\begin{array}{l}\text { Diabetes } \\
(\%)\end{array}$ & $\begin{array}{l}\text { Diagnosis of } \\
\text { hypogonadism }\end{array}$ & Study design & $\begin{array}{l}\text { Adjusted } \\
\text { overall } \\
\text { mortality }\end{array}$ & $\begin{array}{l}\text { Adjusted acute } \\
\text { myocardial } \\
\text { infarction }\end{array}$ \\
\hline $\begin{array}{l}\text { Shores et al }{ }^{28} \\
2012\end{array}$ & 62.1 & $398 / 633$ & 81 & 38 & $\begin{array}{l}\text { TT }<250 \mathrm{ng} / \mathrm{dL} \\
(8.7 \mathrm{nmol} / \mathrm{L})\end{array}$ & $\begin{array}{l}T \text { treatment vs } \\
\text { no treatment }\end{array}$ & $\downarrow$ & NA \\
\hline $\begin{array}{l}\text { Finkle et al, }{ }^{27} \\
2013\end{array}$ & 54.3 & $\begin{array}{l}55593 / \\
141031\end{array}$ & 140 & 18.9 & NA & $\begin{array}{l}\text { TTh prescription } \\
\text { vs PDE5i } \\
\text { prescription }\end{array}$ & NA & $\uparrow$ \\
\hline $\begin{array}{l}\text { Muraleedharan } \\
\text { et } a l_{1}{ }_{1}^{29} 2013\end{array}$ & $45-59$ & $64 / 174$ & 16.5 & 100 & $\begin{array}{l}\mathrm{TT}<300 \mathrm{ng} / \mathrm{dL} \\
(10.4 \mathrm{nmol} / \mathrm{L})\end{array}$ & $\begin{array}{l}\text { T treatment vs } \\
\text { no treatment }\end{array}$ & $\downarrow$ & NA \\
\hline $\begin{array}{l}\text { Vigen et al, } \\
2013\end{array}$ & 63.4 & $1223 / 7486$ & 110 & 55.3 & $\begin{array}{l}\text { TT }<300 \mathrm{ng} / \mathrm{dL} \\
(10.4 \mathrm{nmol} / \mathrm{L})\end{array}$ & $\begin{array}{l}\mathrm{T} \text { treatment vs } \\
\text { no treatment }\end{array}$ & $\uparrow^{*}$ & $\uparrow^{*}$ \\
\hline $\begin{array}{l}\text { Baillargeon } \\
\text { et al }{ }_{1}^{30} 2014\end{array}$ & 66 or older & $\begin{array}{l}6355 / \\
19065\end{array}$ & 182 & 16.3 & NA & $\begin{array}{l}\text { TTh prescription } \\
\text { vs no TTh } \\
\text { prescription }\end{array}$ & NA & $\leftrightarrow$ \\
\hline $\begin{array}{l}\text { Eisenberg et } a l_{,}^{31} \\
2015\end{array}$ & 54.4 & $284 / 225$ & 520 & NA & NA & $\begin{array}{l}\text { TTh prescription } \\
\text { vs no TTh } \\
\text { prescription }\end{array}$ & $\leftrightarrow$ & NA \\
\hline $\begin{array}{l}\text { Etminan et al, } \\
2015\end{array}$ & 70.4 & $\begin{array}{l}30066 / \\
120264\end{array}$ & 145 & 0.3 & NA & $\begin{array}{l}\text { TTh prescription } \\
\text { vs no TTh } \\
\text { prescription }\end{array}$ & NA & $\leftrightarrow$ \\
\hline $\begin{array}{l}\text { Ramasamy } \\
\text { et } a l_{1}^{26} 2015\end{array}$ & 74.3 & $153 / 64$ & 191 & NA & $\begin{array}{l}\mathrm{TT}<300 \mathrm{ng} / \mathrm{dL} \\
(10.4 \mathrm{nmol} / \mathrm{L})\end{array}$ & $\begin{array}{l}T \text { treatment vs } \\
\text { no treatment }\end{array}$ & $\leftrightarrow$ & NA \\
\hline $\begin{array}{l}\text { Sharma et al }{ }_{1}^{33} \\
2015\end{array}$ & 66.2 & $\begin{array}{l}606321 \\
21380\end{array}$ & 304 & 30.6 & $\begin{array}{l}\text { TT lower than the } \\
\text { local laboratory } \\
\text { reference range }\end{array}$ & $\begin{array}{l}T \text { treatment vs } \\
\text { no treatment }\end{array}$ & $\downarrow \S$ & $\downarrow \S$ \\
\hline Tan et al ${ }_{1}^{34} 2015$ & $20-86$ & $\begin{array}{l}19968 / \\
821725\end{array}$ & 72 & 31.3 & $\begin{array}{l}\mathrm{TT}<350 \mathrm{ng} / \mathrm{dL}(12.0 \\
\mathrm{nmol} / \mathrm{L})\end{array}$ & $\begin{array}{l}\text { TTh prescription } \\
\text { vs no TTh } \\
\text { prescription }\end{array}$ & NA & $\downarrow$ \\
\hline $\begin{array}{l}\text { Maggi et al, } \\
2016\end{array}$ & 59.1 & $759 / 249$ & 156 & 28.7 & $\begin{array}{l}\text { TT lower than the } \\
\text { local laboratory } \\
\text { reference range }\end{array}$ & $\begin{array}{l}T \text { treatment vs } \\
\text { no treatment }\end{array}$ & $\leftrightarrow$ & $\leftrightarrow$ \\
\hline $\begin{array}{l}\text { Wallis et } a l_{,}^{36} \\
2016\end{array}$ & 65 or older & $\begin{array}{l}10311 / \\
28029\end{array}$ & 260 & 34.3 & NA & $\begin{array}{l}\text { TTh prescription } \\
\text { vs no TTh } \\
\text { prescription }\end{array}$ & $\downarrow$ & NA \\
\hline
\end{tabular}

randomly allocated to either the group receiving the treatment under investigation or to a group receiving a standard treatment (or placebo), as the control. Randomization reduces selection bias and the different comparison groups allow the researchers to determine any clinical or safety effects of the treatment, when compared with the control group. Several RCTs evaluating the effects of TTh on different outcomes have been published so far. However, properly powered placebo-controlled RCTs with a primary $\mathrm{CV}$ end point, in men with $\mathrm{LOH}$, are not available yet. The available individual trials have had different eligibility criteria, relatively small numbers of participants, different entry $\mathrm{T}$ levels, different $\mathrm{T}$ formulations, different target $\mathrm{T}$ levels, limited durations of treatment, failure to prespecify $\mathrm{CV}$ outcomes, and failure to adjudicate $\mathrm{CV}$ outcomes. The Testosterone in Older Men with Mobility Limitations (TOM) trial represents the best example of the aforementioned limitations. The authors enrolled more than 200 hypogonadal (total $\mathrm{T} \quad 3.5-12.1 \mathrm{nmol} / \mathrm{L}$ or free $\mathrm{T}$ $<173 \mathrm{pmol} / \mathrm{L}$ ) men aged 65 years or older with limitations in mobility to placebo or supraphysiological dose of $\mathrm{T}$ gel (100 mg daily) for 6 months, to evaluate the effect of TTh on exercise tolerance. ${ }^{38}$ Although improved physical function was noted, the trial was ended early on due to increased risk of respiratory, dermatological, and, more importantly, $\mathrm{CV}(\mathrm{T}=23$ vs placebo $=5)$ events in $\mathrm{T}$-treated men. Interestingly, CV events were not adjudicated and several were of minor importance including self-reported syncope and peripheral edema. In addition, the type of population enrolled (frail men) and the use of double of $\mathrm{T}$ recommended dosages further limit the study's evaluation. ${ }^{38}$ More recently, a double-blind, placebo-controlled trial including 170 men aged 65 years or older with an average of two serum $\mathrm{T}$ levels lower than $275 \mathrm{ng} / \mathrm{dL}$ showed that $\mathrm{T}$ gel for 1 year compared with placebo was associated with a significantly greater increase in coronary artery non-calcified plaque volume, as measured by coronary CT angiography. ${ }^{39}$ However, no difference in the incidence of $\mathrm{CV}$ events was observed when T-treated subjects were compared with placebo. ${ }^{39}$ 
Systematic reviews and meta-analyses are often considered as the highest level of evidence, particularly when available data are conflicting. Since 2005, eight systematic meta-analyses on the association between TTh and CV risk are available (table $2^{40-47}$ ). The number of trials considered ranged from 19 to 75 including from 1084 to 5464 subjects. Seven meta-analyses ${ }^{40} 4143-47$ reported outcomes on aggregate CV events, whereas Fernández-Balsells et al ${ }^{42}$ assessed only disaggregate events. The latter were analyzed by four further meta-analyses; ${ }^{40414447}$ however, only our work $^{44}$ included data on MACE. Finally three meta-analyses ${ }^{43} 45 \quad 46$ included only composite events. In particular, two ${ }^{43} 45$ included all $\mathrm{CV}$ events considered as $\mathrm{CV}$ by the investigators, Albert $e a^{46}{ }^{46}$ used a broader definition of events including MACE as well as percutaneous coronary intervention, coronary bypass, syncope and arrhythmias (table 2). Use of composite outcomes increases the number of expected events and could reduce the required sample size and duration of a trial, often improving statistical power. However, major pitfalls are that pooled outcomes vary substantially in their importance to patients, clinicians, and trial investigators. Hence, the magnitude or direction of reported treatment effects can vary across component end points, limiting the scientific value of their use. Figure 1 shows forest plots of estimated OR (95\% CIs) for aggregate or disaggregate CV events as derived from available meta-analyses derived from RCTs on the effect of testosterone therapy (TTh) versus placebo. As shown in the forest plot of figure $1 \mathrm{~A}$, only the meta-analysis of $\mathrm{Xu}$ et $a l^{43}$ found an increased CV risk related to TTh. As mentioned above, it is important to recognize that Xu et $a l^{43}$ in their analysis used a broader definition of $\mathrm{CV}$ events, which included all the events reported as $\mathrm{CV}$ by the investigator report, leading to an artificial increase of the overall number of events. ${ }^{48}$ In all the other meta-analyses no significant risk was associated with the use of TTh, when both aggregate and disaggregate events were considered (figure $1 \mathrm{~A}-\mathrm{C}$ ). However, two systematic reviews showed a significantly increased $\mathrm{CV}$ risk in their subgroup analyses of orally administered $T^{45}{ }^{46}$ In addition, a possible increased CV risk in older individuals ( $>65$ years old) in shorter trials $(<12$ months) has been emphasized by Albert et al. ${ }^{47}$ However, all the latter studies used a composite $\mathrm{CV}$ definition in their analysis. Conversely, when the effect of TTh on MACE was considered, no difference in comparison to placebo was reported. ${ }^{44}$ Interestingly, the evaluation of MACE is what it is required by the regulatory agencies assessing the safety of any drugs. Finally, it is important to recognize that the duration of all studies evaluated in meta-analyses is relatively short, reaching a maximum of 3 years. Therefore, although there is no clear sign of risk in the short term, no information is available on possible long-term effects.

\section{VENOUS THROMBOEMBOLISM RISK}

VTE is a common multifactorial disease with serious complications and potentially fatal outcomes. In the USA alone, VTE causes 600000 hospitalizations and 60000 deaths each year. ${ }^{49}$ Similar results have been reported in Europe. ${ }^{50}$ Major factors underlying VTE include recent surgery or trauma, active cancer, and prolonged immobilization for severe medical diseases. Sex hormones, and in particular estrogens, ${ }^{49}{ }^{50}$ have been considered as a further pathogenetic factor.

\section{Relationship between endogenous T levels and VTE risk}

The contribution of T as a risk factor for VTE in men is controversial. Two large population-based studies failed to find an association between endogenous T and VTE (table 3). ${ }^{51} 52$

In particular, data from the fourth survey of the Tromse study (1994-1995)—which included 1350 communitydwelling men aged 50-84 years-showed a lack of association between endogenous total and free $\mathrm{T}$ and risk of VTE. ${ }^{51}$ Similar results were reported by Holmegard et $a l^{52}$ in the Copenhagen City Heart Study, including 4673 men representative for the adult Danish population. In line with these data, Mumoli et $a l^{53}$ were unable to detect any difference in $\mathrm{T}$ and oestradiol levels between 63 patients with unprovoked deep venous thrombosis (DVT) and matched controls (table 3).

\section{Pharmacoepidemiological studies}

Several case series have documented VTE in patients who received TTh (see for review ref. 56). Possible advocated pathogenetic mechanisms include: (1) hematocrit increase with associated increased blood viscosity, (2) platelet aggregation, and (3) increased thromboxane A2 concentrations in platelets. $^{56}$ In addition, considering that TTh also increases circulating estrogens, it is plausible that the latter may play a role in thrombotic events. ${ }^{56}$ In line with these data, in June 2014 the US FDA ${ }^{12}$ and Health Canada ${ }^{13}$ added a warning regarding the risk of VTE to the label of all $\mathrm{T}$ products, based on postmarketing surveillance reports. However, the vast majority (39 over 40 subjects) of the previously reported cases of TTh-related VTE with measured thrombophilia-hypofibrinolysis was found to have a previously undiagnosed thrombophiliahypofibrinolysis. ${ }^{56}$ Accordingly, when compared with 105 healthy eugonadal controls and with 42 hypogonadal subjects on TTh but without thrombotic events, the 40 cases with thrombotic events were more likely to have Factor V Leiden heterozygosity, higher Factor VIII, and high Factor XI. ${ }^{56}$ More recently, the same authors reported similar results in a study including 347 patients hospitalized for pulmonary embolism (PE). ${ }^{57}$ Hence, by summarizing current evidence deriving from available observational studies, it is important to emphasize as a major limitation the lack of a control group including non-TTh users with a comparable rate of underlying thrombophilia.

To date, only two large pharmacoepidemiological studies have compared the rate of TTh-related VTE with a control group. The first large case-control study included 30572 men 40 years and older who were enrolled in one of the USA's largest commercial insurance programs between January 1, 2007 and December 31, 2012. ${ }^{54}$ Cases were defined as men who had a primary diagnosis of VTE based on International Classification of Diseases, Ninth Revision, and Clinical Modification (ICD-9-CM) codes as primary diagnosis position and received an anticoagulant drug in the 60 days after their diagnoses. Cases were matched with controls who were not diagnosed with DVT or PE at any time during the study period. After the adjustment for confounders, TTh was not associated with an increased risk of VTE (adjusted ratio, 0.90 (0.73 to 1.12$)) .{ }^{54}$ In contrast to 


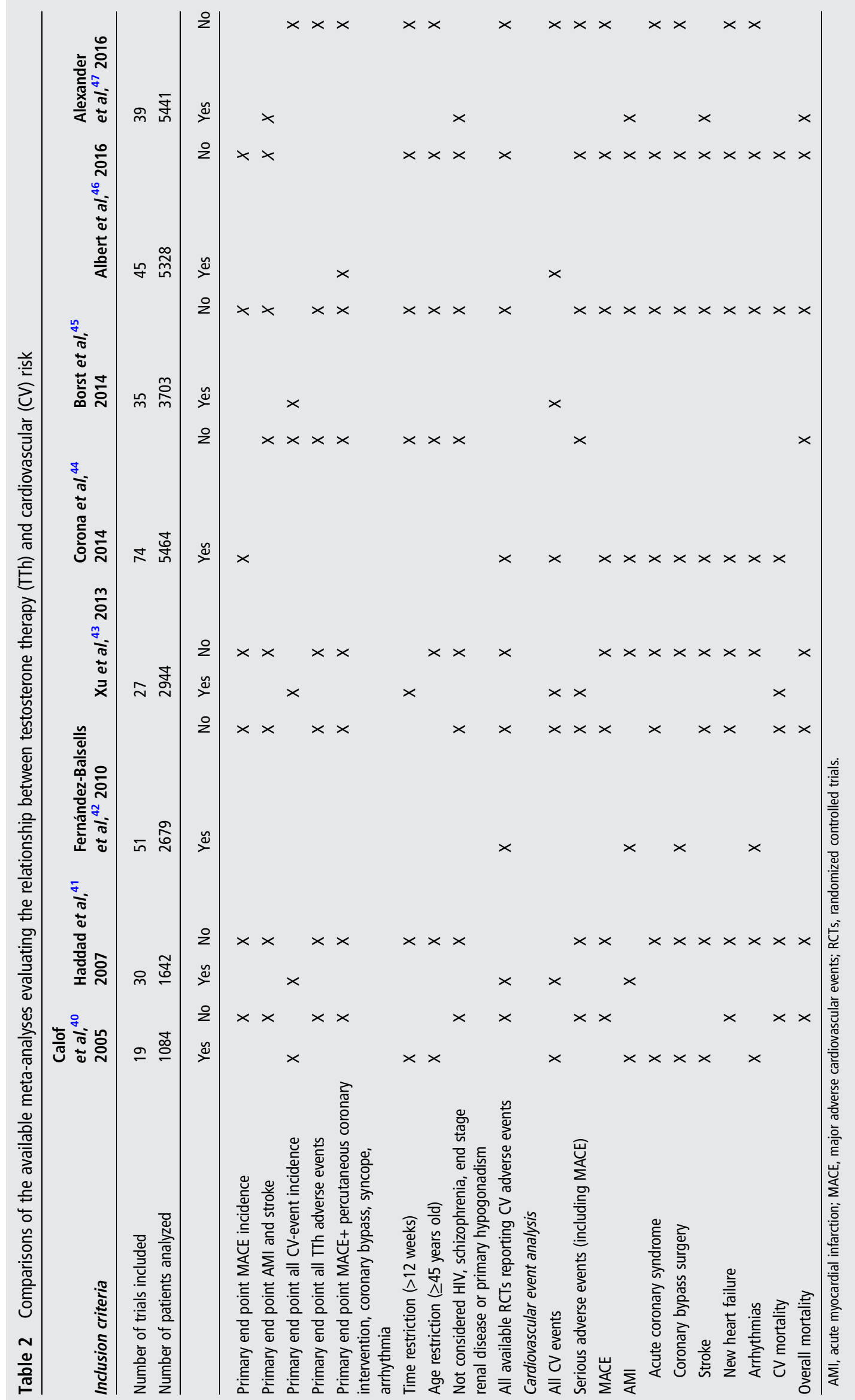


A

\begin{tabular}{l}
\multicolumn{1}{c}{ Source } \\
\hline All CV events \\
Calof et al., 2005 \\
Haddad et al., 2007 \\
Ferandez-Balsells et al., 2010 \\
Xu et al., 2013 \\
Corona et al., 2014 \\
Borst et al., 2014 \\
Albert et al., 2016 \\
Alexander et al., 2016 \\
MACE \\
Calof et al., 2005 \\
Haddad et al., 2007 \\
Ferandez-Balsells et al., 2010 \\
Xu et al., 2013 \\
Corona et al., 2014 \\
Borst et al., 2014 \\
Albert et al., 2016 \\
Alexander et al., 2016 \\
AMI \\
Calof et al., 2005 \\
Haddad et al.,, 2007 \\
Ferandez-Balsells et al., 2010 \\
Xu et al., 2013 \\
Corona et al., 2014 \\
Borst et al., 2014 \\
Albert et al., 2016 \\
Alexander et al., 2016
\end{tabular}

B

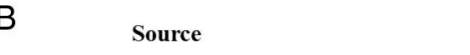

Arrhythmias

Calof et al., 2005

Haddad et al., 2007

Ferandez-Balsells et al., 2010

Xu et al., 2013

Corona et al., 2014

Borst et al., 2014

Albert et al., 2016

Alexander et al., 2016

New Heart Failure

Calof et al., 2005

Haddad et al., 2007

Ferandez-Balsells et al., 2010

Xu et al., 2013

Borst et al., 2014

Albert et al., 2016

Alexander et al., 2016

CV death

Calof et al., 2005

Haddad et al., 2007

Ferandez-Balsells et al., 2010

Xu et al., 2013

Corona et al., 2014

Borst et al., 2014

Albert et al., 2016

Alexander et al., 2016
Corona et al., 2014

Odds ratio for CVD
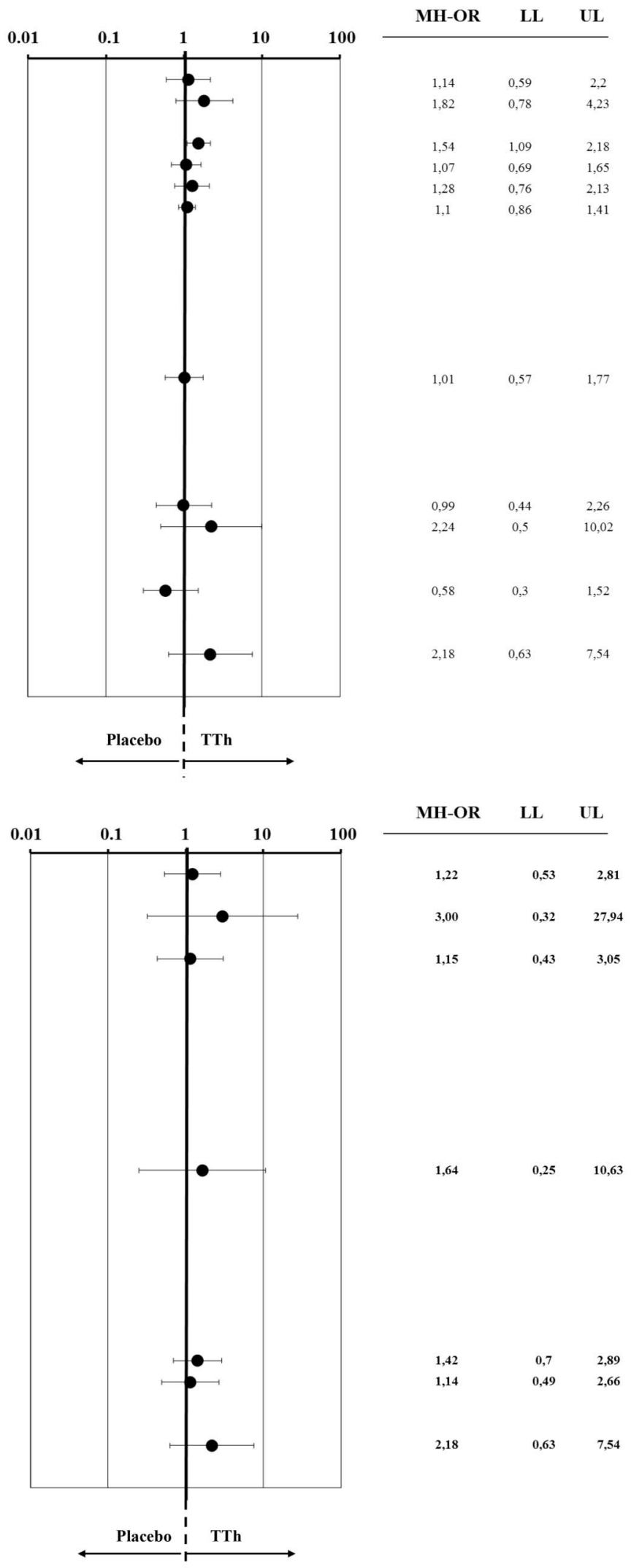

Figure 1 Forest plot of estimated OR $(95 \% \mathrm{Cls})$ for aggregate or disaggregate cardiovascular (CV) disease (CVD) events as derived from available meta-analyses derived from randomized controlled trials on the effect of testosterone therapy (TTh) versus placebo. AMI, acute myocardial infarction; LL, lower limits; MACE, major adverse cardiovascular events; UP, upper limits. 
C

\begin{tabular}{l}
\multicolumn{1}{c}{ Source } \\
\hline Acute coronary syndrome \\
Calof et al., 2005 \\
Haddad et al., 2007 \\
Ferandez-Balsells et al., 2010 \\
Xu et al., 2013 \\
Corona et al., 2014 \\
Borst et al., 2014 \\
Albert et al., 2016 \\
Alexander et al., 2016 \\
Coronary by-pass surgery \\
Calof et al., 2005 \\
Haddad et al., 2007 \\
Ferandez-Balsells et al., 2010 \\
Xu et al., 2013 \\
Corona et al., 2014 \\
Borst et al., 2014 \\
Albert et al., 2016 \\
Alexander et al., 2016 \\
Stroke \\
Calof et al., 2005 \\
Haddad et al., 2007 \\
Ferandez-Balsells et al., 2010 \\
Xu et al., 2013 \\
Corona et al., 2014 \\
Borst et al., 2014 \\
Albert et al., 2016 \\
Alexander et al., 2016 \\
\end{tabular}

Odds ratio for CVD

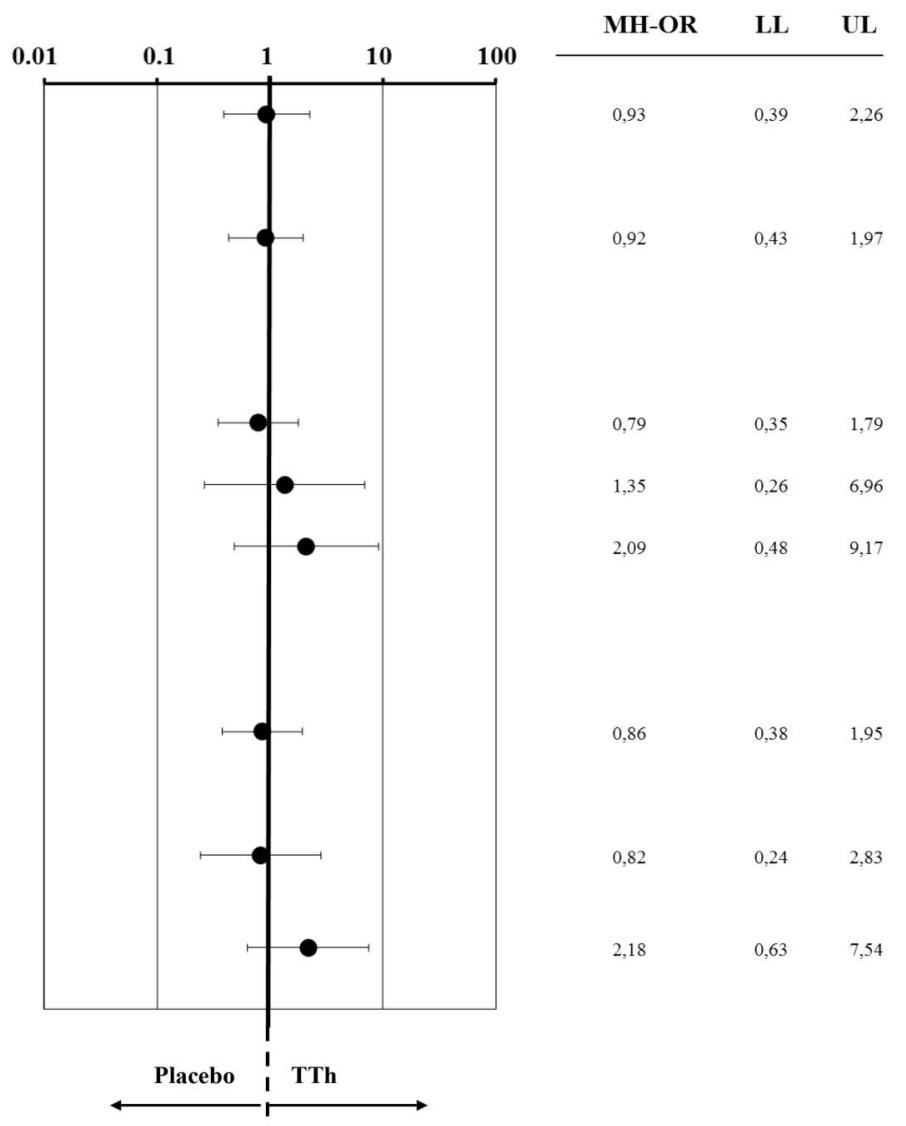

Figure 1 Continued

this study, a more recent report reached opposite findings. ${ }^{55}$ In this study, data were derived from 370 general practitioners in UK primary care, including all men aged 20-89 years registered in the Clinical Practice Research Datalink. Cases comprised 19215 patients with confirmed VTE evaluated between January 2001 and May 2013.
Matched controls included 909530 subjects from the same database not exposed to TTh. The overall adjusted rate ratio of VTE for current versus no TTh was 1.25 (0.94 to 1.66), and, therefore, not statistically significant. However, when the data were limited to the first 6 months of TTh, the rate ratio of VTE was significant, 1.63 (1.12 to 2.37),

Table 3 Characteristics of the longitudinal studies evaluating difference in testosterone (T) levels between subjects with or without venous thromboembolism (VTE) (upper panels) and risk for VTE as derived from available pharmacoepidemiological studies (lower panels)

\begin{tabular}{|c|c|c|c|c|c|c|c|c|}
\hline Study (ref.) & No. of patients & $\begin{array}{l}\text { Follow-up duration } \\
\text { (years) }\end{array}$ & $\begin{array}{l}\text { Age } \\
\text { (years) }\end{array}$ & $\begin{array}{l}\text { Body mass } \\
\text { index }\end{array}$ & DM & Smoking & $\begin{array}{l}\text { Unadjusted risk } \\
\text { of VTE }\end{array}$ & $\begin{array}{l}\text { Adjusted risk of } \\
\text { VTE }\end{array}$ \\
\hline \multicolumn{9}{|c|}{ Risk of VTE based on baseline T levels } \\
\hline $\begin{array}{l}\text { Svartberg et } a l_{,}^{51} \\
2009\end{array}$ & 1350 & 8 & $63 \pm 7$ & $26.1 \pm 3.5$ & 3.8 & 32.1 & - & $1.21(0.62 ; 2.44)^{*}$ \\
\hline $\begin{array}{l}\text { Holmegard et al } l_{1}^{52} \\
2014\end{array}$ & 4673 & 21 & $57(48-65)$ & $26(23-28)$ & 13 & 64 & - & $1.30(0.62 ; 2.73)^{*}$ \\
\hline $\begin{array}{l}\text { Mumoli et } a l_{,}^{53} \\
2015\end{array}$ & 126 & 2 & $64.6 \pm 14.2$ & $26.7 \pm 2.8$ & - & - & - & No difference \\
\hline \multicolumn{9}{|c|}{ Risk of VTE based on TTh exposition in case-control studies } \\
\hline $\begin{array}{l}\text { Baillargeon et al }{ }^{54} \\
2015\end{array}$ & $\begin{array}{l}\text { Cases } 7643 \text { Controls } \\
22929\end{array}$ & - & $\geq 40$ & - & - & - & $0.92(0.75 ; 1.13) \dagger$ & $0.90(0.73 ; 1.12) \dagger$ \\
\hline $\begin{array}{l}\text { Martinez et al }{ }_{1}^{55} \\
2016\end{array}$ & $\begin{array}{l}\text { Cases } 19215 \\
\text { Controls } 909530\end{array}$ & - & $64.8 \pm 15.2$ & $26.0 \pm 4.6$ & - & 19.8 & $1.84(1.42 ; 2.38) \dagger$ & $1.25(0.94 ; 1.66) \dagger$ \\
\hline
\end{tabular}


Table 4 Characteristics of the randomized, placebo-controlled clinical studies included in the meta-analysis on venous thromboembolism risk

\begin{tabular}{|c|c|c|c|c|c|c|c|}
\hline Study (ref.) & $\begin{array}{l}\text { No. of patients } \\
\text { (T/placebo) }\end{array}$ & $\begin{array}{l}\text { Trial duration } \\
\text { (weeks) }\end{array}$ & $\begin{array}{l}\text { Age } \\
\text { (years) }\end{array}$ & Comorbidities & $\begin{array}{l}\text { Baseline total T } \\
\text { (nmol/L) }\end{array}$ & $\mathrm{T}$ levels & Dose \\
\hline $\begin{array}{l}\text { Copenhagen Study } \\
\text { Group, }{ }^{59} 1986\end{array}$ & $134 / 87$ & 112 & 53.0 & $\begin{array}{l}\text { Alcoholic } \\
\text { cirrhosis }\end{array}$ & NR & Mixed & $\begin{array}{l}\text { Micronized T } \\
600 \text { mg/day }\end{array}$ \\
\hline Marin et $a l_{,}^{60} 1993$ & $11 / 10$ & 32 & 57.2 & $\begin{array}{l}\text { Overweight/ } \\
\text { obese }\end{array}$ & 14.8 & Mixed & TG 100 mg/day \\
\hline $\begin{array}{l}\text { Srinivas-Shankar et al, } \\
2010\end{array}$ & $136 / 138$ & 26 & 73.8 & Elderly frail men & 11 & Mixed & TG 50 mg/day \\
\hline Behre et $a l_{,}^{62} 2012$ & $183 / 179$ & 48 & 62.0 & Elderly men & 10,5 & Mixed & TG 50-75 mg/day \\
\hline Brock et al, ${ }^{63} 2016$ & $358 / 357$ & 12 & 55.3 & Elderly men & 6,9 & $<12 \mathrm{nM}$ & $\begin{array}{l}\text { T solution } 2 \% \\
30-60 \mathrm{mg} / \text { day }\end{array}$ \\
\hline Snyder et $a l_{1}^{64} 2016$ & $395 / 395$ & 52 & 72.2 & Elderly men & 8.2 & $<12 \mathrm{nM}$ & TG 50-100 mg/day \\
\hline
\end{tabular}

Study name
Copenaghen study group 1986
Marin et al., 1993
Sinivas-Shankar 2010
Behre et al., 2012
Brocket al., 2016
Snyder et al., 2016
Overall

\begin{tabular}{crrr}
\multicolumn{4}{c}{ Statistics for each study } \\
\hline $\begin{array}{r}\text { Odds } \\
\text { ratio }\end{array}$ & $\begin{array}{c}\text { Lower } \\
\text { limit }\end{array}$ & $\begin{array}{c}\text { Upper } \\
\text { limit }\end{array}$ & p-Value \\
4,66 & 0,24 & 91,29 & 0,31 \\
3,00 & 0,11 & 82,40 & 0,52 \\
2,98 & 0,12 & 73,75 & 0,51 \\
2,95 & 0,12 & 72,91 & 0,51 \\
3,00 & 0,12 & 73,89 & 0,50 \\
1,25 & 0,33 & 4,70 & 0,74 \\
1,96 & 0,75 & 5,17 & 0,17
\end{tabular}

Odds ratio and $95 \% \mathrm{Cl}$
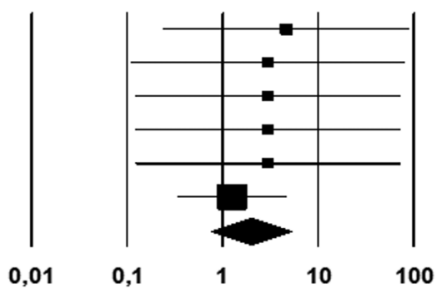

Placebo

TTh

Figure 2 Forest plot of estimated OR (95\% Cls) for venous thromboembolism (VTE) of testosterone treatment (TTh) versus placebo, as derived from available placebo-controlled available trials.

corresponding to 10.0 (1.9 to 21.6) additional VTE above the base rate of 15.8 per10 000 person years. ${ }^{55}$ By meta-analyzing the two aforementioned studies we here report that TTh is not associated with an increased risk of VTE either when unadjusted $(\mathrm{OR}=1.3$ (0.66 to 2.55$)$; $\mathrm{p}=0.46)$ or fully adjusted $(\mathrm{OR}=1.05 \quad(0.76$ to 1.44$)$; $\mathrm{p}=0.78$ ) data were considered (see table 3 and see online supplementary figure $1 \mathrm{~A}, \mathrm{~B})$. Interestingly, the data were confirmed in a sensitivity analysis when events derived from the first 6 months of TTh in the Martinez et $a l^{55}$ study were considered $(\mathrm{OR}=1.19(0.66$ to 2.12$) ; \mathrm{p}=0.56$; see online supplementary figure $1 \mathrm{C})$.

\section{Randomized controlled trial}

The interpretation of epidemiological data is complex because of the effect of confounders. Accordingly, observational studies cannot be used to infer causal relationships, which can be more properly derived from the analysis of RCTs. However, it should be recognized that, no longterm, prospective, intervention RCTs on TTh with VTE or $\mathrm{CV}$ as the primary end point are available. Only results from short-term studies, or obtained from RCTs designed for other purposes, are available. By meta-analyzing the few available data, Xu $e t a l^{58}$ previously reported that TTh was associated with a fivefold increased risk of VTE. However, at that time, the data were only based on three
RCTs, including 516 men. In addition, the authors used a fixed model for their statistical analysis. It is important to recognize that, when a low heterogeneity is detected, a random-effect model should be applied, because the validity of tests of heterogeneity is rather limited, due to the small number of component studies. Hence, in our opinion, results from this meta-analysis are questionable. In order to overcome some of the limitations of the analysis of $\mathrm{Xu}$ et $a l,{ }^{58}$ we here performed an updated systematic review and meta-analysis of RCTs on TTh, including only studies reporting VTE events in T or placebo arms. An extensive Medline search was performed including the following words ("testosterone"[MeSH Terms] OR "testosterone"[All Fields]) AND (Clinical Trial [ptyp] AND "humans"[MeSH Terms] AND English [lang] AND "male"[MeSH Terms]). The search, which accrued data from January 1, 1969 up to December 1, 2016, was restricted to TTh placebo-controlled RCTs on different outcomes, English-language articles, and studies of human participants.

Out of 2904 retrieved articles, six were included in the study. ${ }^{59-64}$ The characteristics of the retrieved trials and the number of events recorded are reported in table 4.

Retrieved trials included 1217 and 1166 patients in TTh and placebo groups, respectively; mean trial duration was 42.0 weeks and mean age 47 years. TTh was administered 
in different cohorts, doses, and formulations (table 4). $\mathrm{I}^{2}$ was $0.0(p=0.96)$. Funnel plot and Begg adjusted rank correlation test (Kendall's $\tau=0.0 ; p=1.0$ ) suggested no major publication bias. By applying a random-effect model, our data indicated that the use of TTh was not associated with any significant difference in the incidence of VTE in comparison to placebo $(\mathrm{MH}-\mathrm{OR}=1.96 \quad(0.75$ to 5.17$)$; $\mathrm{p}=0.17$ ) (figure 2).

\section{CONCLUSIONS}

Men with underlying chronic illnesses, including CV diseases, often have low $\mathrm{T}$, which can be symptomatic (LOH). Although some uncontrolled claims suggest potential risks in treating $\mathrm{LOH}$, data available from controlled trials so far do not suggest any documentable risk, as demonstrated by the Forest plots reported here, summarizing OR results from different meta-analyses. In addition, meta-analysis of RCTs and of the few pharmacoepidemiological studies available does not suggest any relationships between TTh and VTE risk. Hence, TTh, when applied to the right patient (documented $\mathrm{LOH}$ ), should be considered safe and appropriate.

Contributors GC and MM conceptualized and designed the study. GC and $A S, M D, G S, E M$ acquired the data. GC and MM analyzed and interpreted the data. GC and MM drafted the manuscript.

Competing interests None declared.

Provenance and peer review Commissioned; externally peer reviewed.

\section{REFERENCES}

1 Khera M, Adaikan G, Buvat J, et al. Diagnosis and treatment of testosterone deficiency: recommendations from the fourth International consultation for sexual medicine (ICSM 2015). J Sex Med 2016;13:1787-804.

2 Corona G, Ratrelli G, Maggi M. The pharmacotherapy of Male hypogonadism besides androgens. Expert Opin Pharmacother 2015;16:369-87. Review. Erratum in: Expert Opin Pharmacother. 2015;16:941. Ratrelli, Giulia [corrected to Rastrelli, Giulia].

3 Corona G, Rastrelli G, Vignozzi L, et al. Emerging medication for the treatment of Male hypogonadism. Expert Opin Emerg Drugs 2012;17:239-59.

4 Corona G, Isidori AM, Aversa A, et al. Endocrinologic control of men's sexual desire and arousal/erection. J Sex Med 2016;13:317-37.

5 Corona G, Giagulli VA, Maseroli E, et al. Testosterone supplementation and body composition: results from a meta-analysis of observational studies. J Endocrinol Invest 2016;39:967-81.

6 Corona G, Giagulli VA, Maseroli E, et al. Therapy of endocrine disease: testosterone supplementation and body composition: results from a meta-analysis study. Eur J Endocrinol 2016;174:R99-116.

7 Corona G, Vignozzi L, Sforza A, et al. Obesity and late-onset hypogonadism. Mol Cell Endocrinol 2015;418(Pt 2):120-33.

8 Isidori AM, Balercia G, Calogero AE, et al. Outcomes of androgen replacement therapy in adult Male hypogonadism: recommendations from the Italian society of endocrinology. J Endocrinol Invest 2015;38:103-12.

9 Corona G, Maseroli E, Rastrelli G, et al. Is late-onset hypogonadotropic hypogonadism a specific age-dependent disease, or merely an epiphenomenon caused by accumulating disease-burden? Minerva Endocrinol 2016;41:196-210.

10 Morgentaler A, Feibus A, Baum N. Testosterone and cardiovascular disease--the controversy and the facts. Postgrad Med 2015;127:159-65.

11 FDA Drug Safety Communication: FDA cautions about using testosterone products for low testosterone due to aging; requires labeling change to inform of possible increased risk of heart attack and stroke with use. US Food and Drug Administration website. http://www.fda.gov/Drugs/DrugSafety/ ucm436259.htm for HumanMedicalProducts/ucm 402054.htm. Published 3 March 2015 (accessed 20 Dec 2016).

12 Testosterone products: FDA/CDER statement-risk of venous blood clots. US Food and Drug Administration website. http://www.fda.gov/Safety/MedWatch/ Safetylnformation/SafetyAlertsforHumanMedicalProducts/ucm 402054.htm. Published 20 June 2014 (accessed 20 Dec 2016).
13 Summary safety review-testosterone replacement product- cardiovascular risk. Health Canada website. http://www.hc-sc.gc.ca/dhp-mps/medeff/ reviews-examens/testosterone-eng.php. Published 15 July 2014 (accessed 20 Dec 2016).

14 Yeap BB, Grossmann M, McLachlan RI, et al. Endocrine Society of Australia position statement on Male hypogonadism (part 1): assessment and indications for testosterone therapy. Med J Aust 2016;205:173-8.

15 Bartalena L, Bogazzi F, Brogioni S, et al. Role of cytokines in the pathogenesis of the euthyroid sick syndrome. Eur J Endocrinol 1998;138:603-14.

16 Corona G, Rastrelli G, Balercia G, et al. Testosterone and cardiovascular risk in patients with erectile dysfunction. J Endocrinol Invest 2012;35:809-16.

17 Corona G, Rastrelli G, Maseroli E, et al. Low testosterone syndrome protects subjects with high cardiovascular risk burden from major adverse cardiovascular events. Andrology 2014;2:741-7.

18 Rochira V, Diazzi C, Santi D, et al. Low testosterone is associated with poor health status in men with human immunodeficiency virus infection: a retrospective study. Andrology 2015;3:298-308.

19 Nguyen $C P$, Hirsch MS, Moeny D, et al. Testosterone and "Age-Related Hypogonadism"--FDA Concerns. N Engl J Med 2015;373:689-9.

20 Ruige JB, Mahmoud AM, De Bacquer D, et al. Endogenous testosterone and cardiovascular disease in healthy men: a meta-analysis. Heart 2011:97:870-5.

21 Araujo $A B$, Dixon JM, Suarez EA, et al. Clinical review: endogenous testosterone and mortality in men: a systematic review and meta-analysis. J Clin Endocrinol Metab 2011:96:3007-19.

22 Corona G, Rastrelli G, Monami M, et al. Hypogonadism as a risk factor for cardiovascular mortality in men: a meta-analytic study. Eur I Endocrinol 2011;165:687-70.

23 Corona G, Vignozzi L, Sforza A, et al. Risks and benefits of late onset hypogonadism treatment: an expert opinion. World I Mens Health 2013:31:103-25.

24 Corona G, Rastrelli G, Maseroli E, et al. Testosterone replacement therapy and cardiovascular risk: a review. World J Mens Health 2015;33:130-42.

25 Vigen $\mathrm{R}, \mathrm{O}$ 'Donnell $\mathrm{Cl}$, Barón $\mathrm{AE}$, et al. Association of testosterone therapy with mortality, myocardial infarction, and stroke in men with low testosterone levels. JAMA 2013;310:1829-36

26 Ramasamy R, Scovell J, Mederos M, et al. Association between testosterone supplementation therapy and thrombotic events in elderly men. Urology 2015:86:283-5.

27 Finkle WD, Greenland S, Ridgeway GK, et al. Increased risk of non-fatal myocardial infarction following testosterone therapy prescription in men. PLOS ONE 2014;9:e85805.

28 Shores MM, Smith NL, Forsberg CW, et al. Testosterone treatment and mortality in men with low testosterone levels. I Clin Endocrinol Metab 2012;97:2050-8

29 Muraleedharan V, Marsh H, Kapoor D, et al. Testosterone deficiency is associated with increased risk of mortality and testosterone replacement improves survival in men with type 2 diabetes. Eur J Endocrinol 2013;169:725-33.

30 Baillargeon J, Urban RJ, Kuo YF, et al. Risk of myocardial infarction in older men receiving testosterone therapy. Ann Pharmacother 2014;48:1138-44.

31 Eisenberg ML, Li S, Herder D, et al. Testosterone therapy and mortality risk. Int J Impot Res 2015;27:46-8.

32 Etminan M, Skeldon SC, Goldenberg SL, et al. Testosterone therapy and risk of myocardial infarction: a pharmacoepidemiologic study. Pharmacotherapy 2015;35:72-8

33 Sharma R, Oni OA, Gupta K, et al. Normalization of testosterone level is associated with reduced incidence of myocardial infarction and mortality in men. Eur Heart J 2015:36:2706-15.

34 Tan RS, Cook KR, Reilly WG. Myocardial infarction and stroke risk in young healthy men treated with injectable testosterone. Int I Endocrinol 2015;2015:970750.

35 Maggi $\mathrm{M}$, Wu FC, Jones $\mathrm{TH}$, et al. Testosterone treatment is not associated with increased risk of adverse cardiovascular events: results from the Registry of Hypogonadism in Men (RHYME). Int I Clin Pract 2016;70:843-52.

36 Wallis CJ, Lo K, Lee $Y$, et al. Survival and cardiovascular events in men treated with testosterone replacement therapy: an intention-to-treat observational cohort study. Lancet Diabetes Endocrinol 2016:4:498-506.

37 Garnick MB. Testosterone replacement therapy faces FDA scrutiny. JAMA 2015;313:563-4

38 Basaria S, Coviello AD, Travison TG, et al. Adverse events associated with testosterone administration. N Engl J Med 2010;363:109-22. 
39 Budoff MJ, Ellenberg SS, Lewis CE, et al. Testosterone treatment and coronary artery plaque volume in older men with low testosterone. JAMA 2017;317:708-16.

40 Calof OM, Singh AB, Lee ML, et al. Adverse events associated with testosterone replacement in middle-aged and older men: a meta-analysis of randomized, placebo-controlled trials. J Gerontol A Biol Sci Med Sci 2005:60:1451-7.

41 Haddad RM, Kennedy CC, Caples SM, et al. Testosterone and cardiovascular risk in men: a systematic review and meta-analysis of randomized placebo-controlled trials. Mayo Clin Proc 2007;82:29-39.

42 Fernández-Balsells MM, Murad MH, Lane $\mathrm{M}$, et al. Clinical review 1: Adverse effects of testosterone therapy in adult men: a systematic review and meta-analysis. J Clin Endocrinol Metab 2010;95:2560-75.

$43 \mathrm{Xu}$ L, Freeman G, Cowling BJ, et al. Testosterone therapy and cardiovascular events among men: a systematic review and meta-analysis of placebo-controlled randomized trials. BMC Med 2013;11:108.

44 Corona G, Maseroli E, Rastrelli G, et al. Cardiovascular risk associated with testosterone boosting medications: a systematic review and meta-analysis. Expert Opin Drug Saf 2014;13:1327-51.

45 Borst SE, Shuster JJ, Zou B, et al. Cardiovascular risks and elevation of serum DHT vary by route of testosterone administration: a systematic review and meta-analysis. BMC Med 2014;12:211.

46 Albert SG, Morley JE. Testosterone therapy, association with age, initiation and mode of therapy with cardiovascular events: a systematic review. Clin Endocrinol (Oxf) 2016;85:436-43.

47 Alexander GC, lyer G, Lucas $E$, et al. Cardiovascular risks of exogenous testosterone use among men: a systematic review and meta-analysis. Am J Med 2017;130:293-305.

48 Morgentaler A, Miner MM, Caliber M, et al. Testosterone therapy and cardiovascular risk: advances and controversies. Mayo Clin Proc 2015;90:224-51.

49 Grosse SD, Nelson RE, Nyarko KA, et al. The economic burden of incident venous thromboembolism in the United States: a review of estimated attributable healthcare costs. Thromb Res 2016;137:3-10.

50 Cohen AT, Agnelli G, Anderson FA, et al. Venous thromboembolism (VTE) in Europe. The number of VTE events and associated morbidity and mortality. Thromb Haemost 2007;98:756-64.

51 Svartberg J, Braekkan SK, Laughlin GA, et al. Endogenous sex hormone levels in men are not associated with risk of venous thromboembolism: the Tromso study. Eur J Endocrinol 2009;160:833-8.
52 Holmegard HN, Nordestgaard BG, Schonohr P, et al. Endogenous sex hormones and risk of venous thromboembolism in women and men. J Thromb Haemost 2014:12:297-305.

53 Mumoli N, Cei M, Giorgi Pierfranceschi M, et al. Endogenous sex hormone levels in men with unprovoked deep-vein thrombosis. Thromb Haemost 2015;114:438-9

54 Baillargeon J, Urban RJ, Morgentaler A, et al. Risk of venous thromboembolism in men receiving testosterone therapy. Mayo Clin Proc 2015:90:1038-45.

55 Martinez C, Suissa S, Rietbrock S, et al. Testosterone treatment and risk of venous thromboembolism: population based case-control study. BMJ 2016;355:i5968. doi: 10.1136/bmj.i5968.

56 Glueck CJ, Wang P. Testosterone therapy, thrombosis, thrombophilia, cardiovascular events. Metab Clin Exp 2014;63:989-94.

57 Prince $\mathrm{M}$, Glueck CJ, Shah $\mathrm{P}$, et al. Hospitalization for pulmonary embolism associated with antecedent testosterone or estrogen therapy in patients found to have familial and acquired thrombophilia. BMC Hematol 2016;16:6.

$58 \mathrm{Xu} \mathrm{L}$, Schooling CM. Differential risks in men and women for first and recurrent venous thrombosis: the role of genes and environment: comment. J Thromb Haemost 2015;13:884-6.

59 Testosterone treatment of men with alcoholic cirrhosis: a double blind study. The Copenhagen Study Group for Liver Diseases. Hepatology 1986;6:807-13.

60 Marin P, Holmang S, Gustafsson C, et al. Androgen treatment of abdominally obese men. Obes Res 1993;1:245-51.

61 Srinivas-Shankar U, Roberts SA, Connolly MJ, et al. Effects of testosterone on muscle strength, physical function, body composition, and quality of life in intermediate-frail and frail elderly men: a randomized, double-blind, placebo-controlled study. J Clin Endocrinol Metab 2010;95:639-50.

62 Behre HM, Tammela TL, Arver S, et al. A randomized, double-blind, placebo-controlled trial of testosterone gel on body composition and health related quality-of-life in men with hypogonadal to low-normal levels of serum testosterone and symptoms of androgen deficiency over 6 months with 12 months open-label follow-up. Aging Male 2012;15:198-207.

63 Brock $\mathrm{G}$, Heiselman $\mathrm{D}$, Maggi $M$, et al. Effect of testosterone solution $2 \%$ on testosterone concentration, sex drive and energy in hypogonadal men: results of a placebo controlled study. J Urol 2016;195:699-705.

64 Snyder PJ, Bhasin S, Cunningham GR, et al. Effects of testosterone treatment in older men. N Engl J Med 2016;374:611-24. 